\title{
Su Kalitesinin İnsansız Hava Aracı Verileri ve Fiziko-Kimyasal Parametrelerin Analizi ile Belirlenmesi: Aydınlar (Gülüç) Çayı Örneği
}

\author{
Nizamettin Özdoğan ${ }^{1 *}$, Umut Güneş Sefercik², Yağmur Kılınç ${ }^{1}$, Emine Çalışkan ${ }^{1}$, Can Atalay ${ }^{1}$ \\ 1*Bülent Ecevit University, Faculty of Engineering, Environmental Engineering, Zonguldak, Turkey, (ORCID: 0000-0001-5520-5124), nozdogan256@gmail.com \\ ${ }^{2}$ Gebze Techinal University, Faculty of Engineering, Dept. of Geomatics Engineering, Kocaeli, Turkey, (ORCID: 0000-0003-2403-5956), ugsefercik@hotmail.com \\ ${ }^{1}$ Bülent Ecevit University, Faculty of Engineering, Environmental Engineering, Zonguldak, Turkey, (ORCID: 0000-0002-6325-1718), yagmur.klnc@yahoo.com \\ ${ }^{1}$ Bülent Ecevit University, Faculty of Engineering, Environmental Engineering, Zonguldak, Turkey, (ORCID: 0000-0003-3926-2166), eminecaliskan196@gmail.com \\ ${ }^{1}$ Bülent Ecevit University, Faculty of Engineering, Dept. of Geomatics Engineering, Zonguldak, Turkey, (ORCID: 0000-0002-6499-8071), canatalay@beun.edu.tr
}

(İlk Geliş Tarihi 26 Şubat 2021 ve Kabul Tarihi 05 Nisan 2021)

(DOI: 10.31590 /ejosat.887105)

ATIF/REFERENCE: Ozdogan, N., Sefercik, U.G., Kılınç, Y., Çalışkan, E. \& Atalay, C. (2021). Su Kalitesinin İnsansız Hava Aracı Verileri ve Fiziko-kimyasal Parametrelerin Analizi ile Belirlenmesi: Aydınlar (Gülüç) Çayı Örneği. Avrupa Bilim ve Teknoloji Dergisi, (23), 572-582.

$\ddot{\mathbf{O} z}$

Bu çalışmada, sulama suyu amaçlı kullanılan Aydınlar (Gülüç) çayının fiziko-kimyasal parametreler açısından su kalitesi incelenmiş ve insansız hava aracı (İHA) verilerinin spektral analizi ile karşılaştırmalı değerlendirmeleri yapılmıştır. Çalışma kapsamında, su kalitesini belirlemek için üç farklı numune alım noktası belirlenmiş ve Haziran 2019 (kurak dönem), Eylül 2019 ve Aralık 2019 (yağışlı dönem) tarihlerinde çayı temsilen su numuneleri alınmıştır. Alınan numunelerin pH, elektriksel iletkenlik (EI), bulanıklık, askıda katı madde (AKM), sıcaklık değerleri ile kimyasal oksijen ihtiyacı (KOİ), biyokimyasal oksijen ihtiyacı (BOİ5), çözünmüş oksijen (ÇO), toplam kjeldahl azotu (TKA), toplam fosfat (TP) ve yağ-gres analizleri gerçekleştirilmiştir. pH, Eİ, bulanıklık, sıcaklık ve AKM değerleri sırasiyla ortalama 7.67-8.32, 815-1106 $\mu \mathrm{S} / \mathrm{cm}, 14.91-20.95 \mathrm{NTU}, 9.34-25.34{ }^{\circ} \mathrm{C}$ ve $32.84-82.67 \mathrm{mg} / \mathrm{L}$ arasında, ÇO, BOİ, KOİ, TP, TKA ve yağ-gres değerleri ise sirasiyla ortalama $2.34-3.40 \mathrm{mg} / \mathrm{L}, 8.14-20.14 \mathrm{mg} / \mathrm{L}, 96.44-132.7 \mathrm{mg} / \mathrm{L}, 0.179-0.296 \mathrm{mg} / \mathrm{L}, 13.91-20.14$ $\mathrm{mg} / \mathrm{L}$ ve $0.0087-0.016 \mathrm{mg} / \mathrm{L}$ arasında ölçülmüştür. Tespit edilen fiziko-kimyasal parametreler Yerüstü Su Kalitesi Yönetmeliği (YSKY)'ne göre değerlendirilmiştir. Ayrıca, belirlenen fiziko-kimyasal parametrelerin su yüzeyinde meydana getirdiği spektral (renk) değişimler, yüksek çözünürlüklü kamera donanımına sahip İHA ile elde edilen hava fotoğraflarının işlenmesi sonucu üretilen ortomozaikler üzerinden analiz edilmiştir. Sonuç olarak, Aydınlar Çay’ının ÇO, BOİ5, KOİ, TP ve TKA ortalama konsantrasyonları YSKY'in de belirtilen değerlere göre III. Sınıf ve IV. Sınıf su kalite özelliği gösterdiği tespit edilmiştir.

Anahtar Kelimeler: Aydınlar Çayı, Su Kalitesi, Fiziko-Kimyasal Parametreler, İnsansız Hava Aracı.

\section{Determination of Water Quality by Analysing Unmanned Aerial Vehicle Data and Physico-Chemical Parameters: The Case of Aydınlar (Gülüç) Stream}

\begin{abstract}
In this study, the water quality of Aydınlar (Gülüç) Stream, which is used for irrigation, has been examined in terms of physico-chemical parameters and comparative evaluations were realized with spectral analysis of unmanned aerial vehicle (UAV) data. Within the scope of this study, we determined three distinct locations to collect water samples for evaluation and water samples were taken to represent the water quality of the stream in the periods such as, June 2019 (dry period) and September and December 2019 (rainy periods). The samples were evaluated in terms of their $\mathrm{pH}$ levels, electrical conductivities (EI), turbidities, total suspended solids (TSS), temperature values and chemical oxygen demands (COD), biochemical oxygen demands (BOD5), dissolved oxygen (DO) levels, total kjeldahl nitrogen (TKN), total phosphate (TP) and oil-grease analysis. Average $\mathrm{pH}$, conductivity, turbidity, temperature and TSS values were measured respectively, 7.67-8.32, 815-1106 $\mu \mathrm{S} / \mathrm{cm}, 14.91-20.95 \mathrm{NTU}, 9.34-25.34{ }^{\circ} \mathrm{C}$ and between $32.84-82.67 \mathrm{mg} / \mathrm{L}$; DO, BOD5, COD, TP, TKN and oil-grease values measured average respectively as; $2.34-3.40 \mathrm{mg} / \mathrm{L}, 8.14-20.14 \mathrm{mg} / \mathrm{L}$ between $96.44-132.7 \mathrm{mg} / \mathrm{L}$, 0.179-0.296 mg/L, 13.91-20.14 mg/L and 0.0087-0.016 mg/L. Detected physico-chemical parameters have been evaluated according to the Surface Water Quality Regulation (SWQR). In addition, the determined spectral changes on the water surface caused by the physico-chemical parameters were analyzed over generated ortho-mosaics by processing aerial photos obtained with high-resolution camera equipped UAV. As a result, we can state that Aydınlar Stream's water's average concentrations of DO, BOD5, COD, TP and TKN levels, according to the values specified in SWQR, show III. class and IV class water quality properties.
\end{abstract}

Keywords: Aydinlar Stream, Water Quality, Physico-Chemical Parameters, Unmanned Aerial Vehicle.

*Sorumlu Yazar: nozdogan256@gmail.com 


\section{Giriş}

Su, dünyadaki yaşam için gerekli temel kaynaktır. Bu değerli kaynağı kullanma şeklimiz sadece sağlığımızı değil aynı zamanda suya bağlı yaşamı da etkilemektedir. Bu yaşamsal değer üzerinde ki baskı her geçen gün artmakta dolayısıyla su sorunu ile karşı karşıya kalan insan toplulukları da ciddi boyutta sıkıntılar ile karşı karşıya kalmaktadır (Güler ve Çobanoğlu, 1997). Son yıllarda, dünya da kullanılan tatlı su miktarında önemli artışlar görülmektedir. Kısıtlı olan tatlı su kaynakları üzerindeki çeşitli baskılar suya erişimde ve su kalitesiyle ilgili bazı problemlerin ortaya çıkmasına neden olmaktadır. Artan nüfus, şehirleşme, sanayileşme, gelir ve tüketim seviyesinin yükselmesi, kirletici maddeler, sucul ekosistemlerde ki fiziksel değişimler ve iklim değişikliği, suyun kalitesini ve kullanılabilirliğini zayıflatmaktadır. $\mathrm{Bu}$ nedenle, kullanılan su kaynaklarının korunması, kalite bileşenlerinin belirlenmesi, izlenmesi ve su kalite yönetiminin oluşturulması büyük önem taşımaktadır. Ülkemizde; Sakarya, Büyük Menderes, Kızılırmak, Susurluk ve Aydınlar Çayı v.b. gibi büyük doğal yüzeysel su kaynaklarının \%79'u kirlenmiştir (URL-1, 2018). Bu kaynaklarımızın içme, sulama ve kullanma suyu olarak kullanılması hem su ortamında yaşayan canlıları hem de çevre ve insan sağlığını tehdit etmektedir. Maden ocakları başta olmak üzere termik santrallerin, endüstriyel işletmelerin bulunması ve bunların faaliyetleri sonucunda ortaya çıkan kirlilik ildeki su kaynaklarını kirletmektedir (URL-2, 2018). Bu bağlamda, suların kirlilik seviyeleri ölçmek ve kullanılabilirliğini belirlemek için bazı fiziko-kimyasal parametreler önem teşkil etmektedir. $\mathrm{Bu}$ parametrelerin sınır değerlerine uygunlukları "Yerüstü Su Kalitesi Yönetmeliği” (YSKY)'ne göre yapılmaktadır. Bu yönetmelikle, "yüzeysel sular ile kıyı ve geçiş sularının biyolojik, kimyasal, fiziksel ve hidromorfolojik kalitelerinin belirlenmesi ve sınıflandırılması" amaçlanmaktadır (YSKY, 2016).

Son y1llarda, su kirliliği seviyelerinin tespiti için destek niteliğinde olan bir diğer araştırma yöntemi ise modern haritalama teknolojilerinden elde edilen veriler çerçevesinde kurulan Coğrafi Bilgi Sistemleri (CBS)'dir. CBS, coğrafi ham verilerin hava ve uzay kaynaklı platformalardan elde edilmesi, bilgisayar ortamında işlenerek yüksek koordinat doğruluğu ile konumlanması, iki ve üç boyutlu (3B) olarak analiz edilmesi ve istenilen amaçlar doğrultusunda kullanılması için geliştirilmiş bütünleşik bir sistemdir. CBS'den ayrıca, su kaynaklarının tespiti ve yönetimi, taşkın analizi ve afet yönetimi konularında da faydalanılmaktadır. CBS'nin gerek konumsal veri üretimi ve gerekse harita altlığını oluşturmada İnsansız Hava Aracı İHA'lardan da yararlanılabilmektedir. İHA teknolojisi hem optik (kameralı) hem de lazer tarama (lazer tarayıcılı) kabiliyeti ile periyodik, çok yüksek çözünürlüklü ve doğruluklu hava fotoğrafları, nokta bulutları ve üç boyutlu topoğrafik modeller sağlayabilen, çok farklı disiplinlerden bilimsel ve ticari kullanıcıların yoğun talep gösterdiği son dönemin en popüler uzaktan algilama teknolojilerinden biridir (Sefercik ve ark., 2018, Karakış ve ark., 2018).

Literatürde Aydınlar Çayı ile ilgili yapılan farklı çalışmalar bulunmaktadır. $\mathrm{Bu}$ çalışmalardan biri Sediman içerisinde ki kirlilik boyutunu göstermek için Aydınlar Çayının Karadeniz ile buluştuğu noktadan alınan su örnekleriyle yapılan ağır metal kirliliğinin bakıldığı çalışmadır (Sur ve ark., 2012). Diğer bir çalışma, Aydınlar çayının yine Karadeniz'e döküldüğü yerden e-ISSN: 2148-2683 alınan su örnekleri ile yıllık kirlilik yükünün hesaplandığı çalışmadır (Bat ve Özkan, 2015). Başka bir çalışmada ise Aydınlar çayının denize döküldüğü bölgede tutulan kefal balıklarında glutatyon s transferaz, katalaz ve PAH değerleri araştırılmış ve bu parametreler aracılığıyla kirlilik rapor edilmiştir (Bozcaarmutlu ve ark., 2009).

Bu çalışmada, sulama suyu olarak kullanılan Aydınlar Çayının 3 farklı noktasından alınan su örnekleri ile su kalite parametreleri belirlenmiş ve İHA verilerinin spektral analiziyle karşılaştırılmıştır. İHA spektral analiz sonuçları, laboratuar ortamında elde edilen su numune analiz sonuçları ile kıyaslanarak bilimsel yorumlamalar gerçekleştirilmiştir. Elde edilen veriler YSKY'ne göre yorumlanmış ve su kalite sınıfları tespit edilmiştir. Tüm bu yönleriyle bu çalışma, Aydınlar Çay’ında yapılan ilk kapsamlı su kalite analizi çalışmasıdır.

\section{Materyal ve Metot}

\section{1. Çalışma Alanı}

Çalıșma alanı, Zonguldak ili Ereğli ilçesinde bulunan ve Zonguldak-Devrek sınırındaki Hörgüç civarından doğan ırmak, birçok dere ve dereciğin sularıyla beslenerek Gülüç mevkiinde yer alan Aydınlar Çayıdır. Zonguldak ili, ılıman bir Karadeniz iklimine sahip ve çoğunlukla tüm mevsimler yağışlı geçmektedir. İlin ortalama sıcaklık değeri $13.7{ }^{\circ} \mathrm{C}$ dir. En düşük sıcaklık değerleri Aralık-Ocak-Şubat aylarında, en yüksek sıcaklık değerleri ise Haziran-Temmuz-Ağustos aylarında ölçülmektedir (URL-3, MGM). Coğrafi Konum Yer Koordinatları; Enlem: $41^{\circ}$ 16' 0“ K Boylam: 31 31' 0“ olan Aydınlar Çayının uzunluğu 84 km'dir. Debisi $21.887 \mathrm{~m} 3 / \mathrm{sn}$ dir. Çayın su alma kapasitesi ise 1400 ton/gün'dür. Hizmet verdiği nüfus sayısı ise 7800 kişi/gün'dür (URL-2, 2018). Bu çalışmada, Aydınlar Çayı'nın seçilme nedeni bölgenin sulama suyu ihtiyacının sağlandığ önemli bir yüzeysel su kaynağı olmasıdır. Aydınlar Çayı, havzasında geniş yayılım gösteren tarım arazileri, demir-çelik üretimi yapan tesisler, küçük sanayi bölgeleri, kentsel yerleşik alanlar, kentsel gelişme alanları ve diğer endüstriyel sektörler bulunmaktadır (Şekil 1).

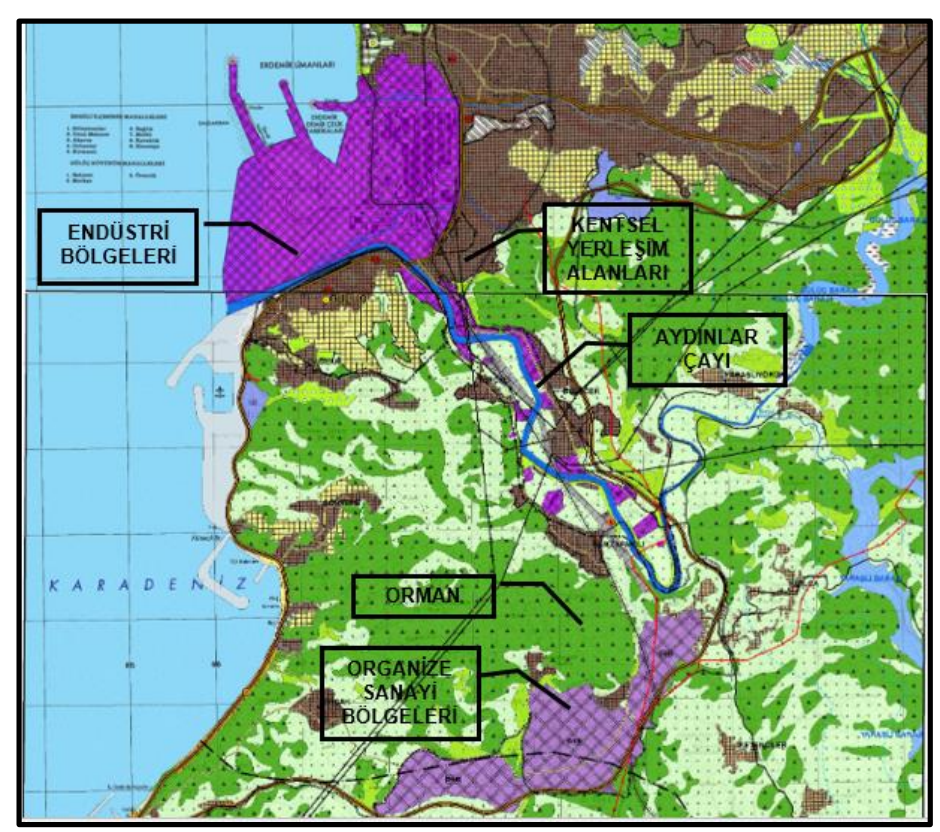

Şekil 1. Zonguldak 1:25.000 Ölçekli Çevre Düzeni Planı (URL4). 
Aydınlar Çayı üzerinde su numunesi alınan ve İHA uçuşları gerçekleştirilen çalışma alanları Şekil 2'de gösterilmiştir. Şekil 2'de 1 no'lu alanda, Ereğli Demir-Çelik Fabrikası (Erdemir) bulunması nedeniyle bu alan Erdemir olarak isimlendirilmiştir. Bu alan aynı zamanda Karadeniz'in Aydınlar Çayı ile birleşme bölgesidir. 2 no'lu alanda Tat-metal Çelik Sanayi yerleşimi bulunması nedeniyle bu alan Tat-metal olarak isimlendirilmiştir. 3 no'lu alan ise, endüstri yoğunluğunun olduğu diğer iki alanın aksine Hamzafakılı Köyü'ne yakın evsel ve tarımsal arazilerin bulunduğu bir bölgedir ve alan Hamzafakılı olarak isimlendirilmiştir.

\subsection{Materyaller}

Su numunelerinin alındığı üç ayrı bölgede iki periyot (kurak ve yağışlı dönem) halinde gerçekleştirilen İHA uçuşlarında, DJI Phantom IV İHA ve her uçuş alanında ayrı ayrı konumlandırılan yer kontrol noktalarının (YKN) ölçümleri için SATLAB SL600 Global Navigasyon Uydu Sistemleri (GNSS) alıcıları kullanılmıştır. Tablo 1'de, kullanılan İHA, GNSS alıcıları ve tesis edilen YKN'lerin teknik özellikleri sunulmuştur.

\subsection{Su Numune Alımı}

Aydınlar Çay’ından Haziran 2019 (kurak dönem), Eylül ve Aralık 2019 (yağışlı dönem) olmak üzere üç farklı dönemde alınan su numuneleri laboratuvar ortamında analiz edilmiştir. $\mathrm{Su}$ numunelerine ait su kalite parametreleri; elektriksel iletkenlik, bulanıklık, askıda katı madde (AKM), sıcaklık, çözünmüş oksijen, pH, kimyasal oksijen ihtiyacı (KOİ), biyolojik oksijen ihtiyacı (BOİ5), toplam fosfat, toplam kjeldahl azotu (TKA) ve yağ gres olarak belirlenmiştir. Su numuneleri laboratuvar ortamında $4{ }^{\circ} \mathrm{C}$ de muhafaza edilmiştir.

\subsection{Numune Alma Prosedürü}

Bu çalışmada, 84 km uzunluğunda ki Aydınlar çayı boyunca üç farklı noktadan üç ayrı zamanda alınmış su numunelerinin alım noktaları ve noktalara ilișkin koordinat değerleri Tablo 2'de sunulmuştur. Koordinat değerleri hem Coğrafi Dünya Jeodezi Sistemi 1984 (WGS84) hem de Enlem Merkatoru (TM) 33. dilime göre sunulmuştur. Su numunesi alım işlemi, Su Kirliliği Kontrolü Yönetmeliği Numune Alma ve Analiz Metotları Tebliği temel alınarak gerçekleştirilmiştir.

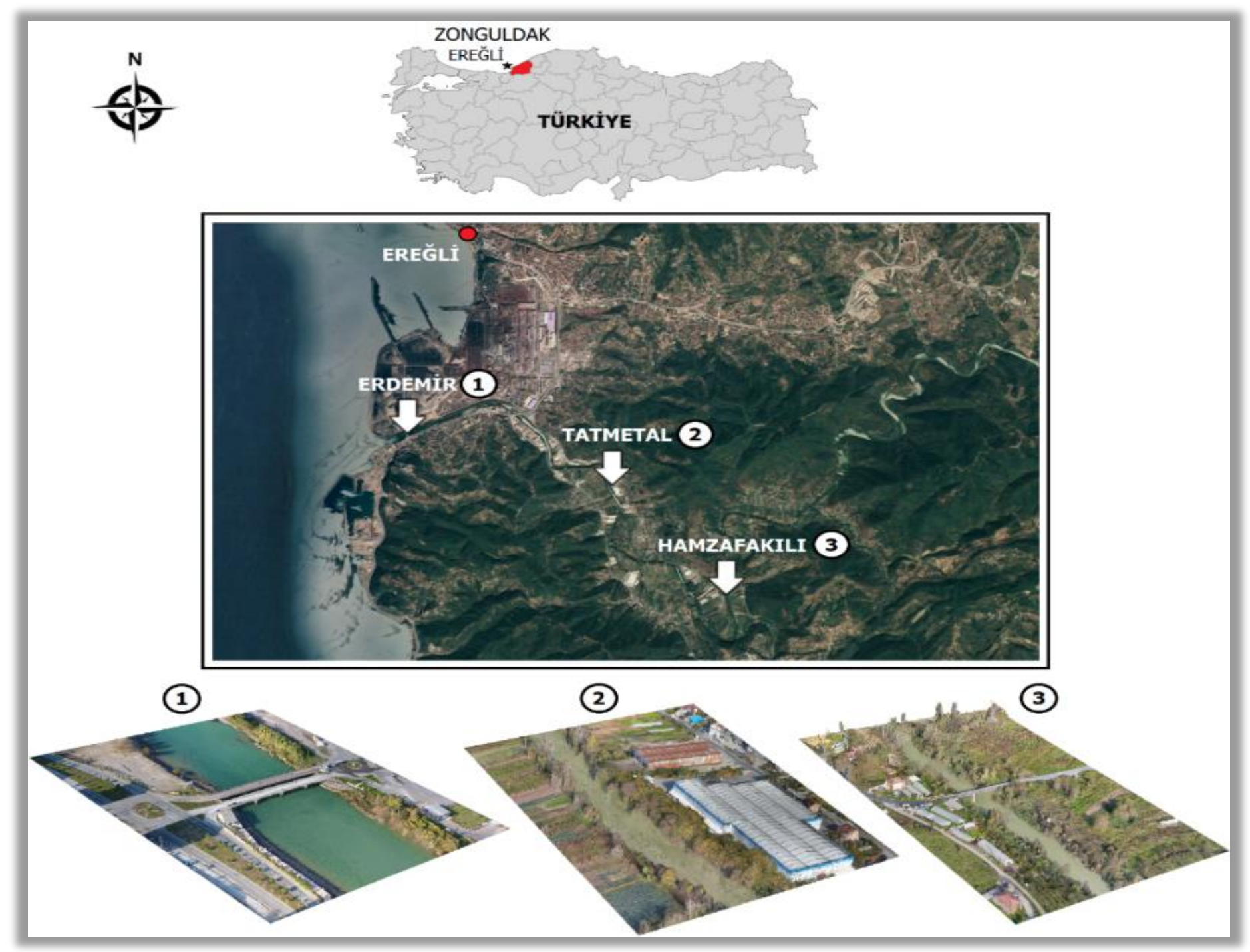

Şekil 2. Çalışma alanları: (1) Erdemir çalışma alanı, (2) Tatmetal çalışma alanı, (3) Hamzafakılı çalışma alanı 


\begin{tabular}{|c|c|c|c|}
\hline \multicolumn{4}{|c|}{ İHA Uygulaması Materyallerleri } \\
\hline \multicolumn{2}{|c|}{ DJI Phantom IV İHA } & \multicolumn{2}{|c|}{ SATLAB SL 600 GNSS + YKN } \\
\hline Kamera & $\begin{array}{c}\text { 4K, HD, 1080p, } \\
1 / 2.3 ", \text { efektif } \\
\text { piksel } 12.4 \mathrm{MP}\end{array}$ & GNSS teknolojisi & $\begin{array}{c}\text { 6G; GPS, GLONASS, } \\
\text { GALILEO, BeiDou, SBAS, } \\
\text { QZSS }\end{array}$ \\
\hline Gimbal & $\begin{array}{l}\text { 3-eksenli (pitch, } \\
\text { roll, yaw) }\end{array}$ & Operasyon sistemi & Linux \\
\hline Uçuş süresi & $\begin{array}{c}\text { Tek uçuşta } \\
\text { maksimum } 28 \\
\text { dakika }\end{array}$ & Çalışma modları & $\begin{array}{l}\text { Statik, VRS RTK, UHF RTK, } \\
\text { tüm ölçüm modları }\end{array}$ \\
\hline A ğırlık & $1380 \mathrm{gr}$ & Dahili bellek & $1 \mathrm{~GB}$ \\
\hline Hız & $\begin{array}{l}\text { Maksimum } 20 \\
\mathrm{~m} / \mathrm{s}\end{array}$ & RTK Konum doğruluğu & $\begin{array}{c}0.8 \mathrm{~cm} \mathrm{H}, 1.5 \mathrm{~cm} \mathrm{~V} \text { with } \\
99.9 \% \text { confidence level }\end{array}$ \\
\hline $\begin{array}{l}\text { Rüzgar hızına } \\
\text { mukavemeti }\end{array}$ & $\begin{array}{l}\text { Maksimum } 10 \\
\mathrm{~m} / \mathrm{s}\end{array}$ & Pil & $\begin{array}{c}\text { Dual; } 24 \mathrm{~h} \text { statik, } 18 \text { h RTK } \\
\text { baz, } 15 \text { h RTK gezici }\end{array}$ \\
\hline Operasyonel isı & $0^{\circ}-40^{\circ}$ & TUSAGA-Aktif & Mevcut \\
\hline GNSS modülü & $\begin{array}{c}\text { GPS + } \\
\text { GLONASS dual }\end{array}$ & YKN rengi ve malzemesi & Beyaz polikarbon \\
\hline $\begin{array}{l}\text { Konum } \\
\text { doğruluğu }\end{array}$ & $\begin{array}{c}0.1 \mathrm{~m} \text { Düşey, } 0.3 \\
\text { m Yatay (görüş); } \\
0.5 \mathrm{~m} \text { Düşey, } 1.5 \\
\text { m Yatay (GPS) }\end{array}$ & YKN boyutları (boy×en) & $1.00 \mathrm{~m} \times 0.25 \mathrm{~m}$ \\
\hline
\end{tabular}

Tablo 2. Su numunelerinin alım noktaları ve noktalara ait koordinat değerleri

\begin{tabular}{|c|c|c|}
\hline Erdemir & Tatmetal & Hamzafakıl \\
\hline Coğrafi: & Coğrafi: & Coğrafi: \\
$41^{\circ} 14^{\prime} 59.57^{\prime \prime}, 31^{\circ} 24^{\prime} 41.56 " \mathrm{E}$ & $41^{\circ} 14^{\prime} 27.29^{\prime \prime} \mathrm{N}, 31^{\circ} 26^{\prime} 37.68 \mathrm{E}$ & $41^{\circ} 133^{\prime 2} 28.33^{\prime \prime} \mathrm{N}, 31^{\circ} 27^{\prime} 49.73^{\prime \prime} \mathrm{E}$ \\
\hline TM: $366858.6352,4569541.2557$ & $\mathrm{TM}: 369544.5637,4568496.3968$ & $\mathrm{TM}: 371190.2047,4566647.4257$ \\
\hline & & \\
\hline
\end{tabular}




\subsection{Su Kalitesi Analizleri}

Aydınlar Çayının su kalite parametrelerini belirlemek için üç ayrı dönemde alınmış su numuneleri aynı gün Zonguldak Bülent Ecevit Üniversitesi Çevre Mühendisliği Bölümü laboratuvarına getirilerek fiziksel ve kimyasal analizleri gerçekleştirilmiştir. Fiziksel parametreler; Thermo Scientific Orion 5 Star cihazı kullanılarak suyun sıcaklığ $\left({ }^{\circ} \mathrm{C}\right)$, ve elektriksel iletkenlik $(\mu \mathrm{S} / \mathrm{cm})$ değerleri tespit edilmiştir. AKM miktarı, sabit tartım yöntemiyle, bulanıklık ise türbidimetre cihazı ile direkt ölçülmüştür. Kimyasal parametreler; pH ölçümleri standard solüsyonlar kullanılarak (Thermo Scientific Orion 5 Star), KOİ değeri kapalı reflux yöntemi ile $\mathrm{BOI்}_{5}$ değeri ise, organik maddenin parçalanması sonucu açığa çıkan $\mathrm{CO}_{2}$ 'nin kısmı basıncının oksitop (WTW Weilheim, Almanya) cihazıyla ölçülmesi sonucu belirlenmiştir. Fosfor tayini kolorimetrik kalay klorür metoduyla, yağ-gres analizleri sokslet aparatının hekzanla birlikte ektraksiyonu işlemiyle ve TKA ise, Büchi Digest System K-437 cihazı kullanilarak distilasyon-amonyak tayin metoduyla tespit edilmiştir. Örneklem noktalarından alınan su örneklerinin fiziksel ve kimyasal analizleri standard metodlar baz alınarak yapılmıştır (APHA, 2005). Su kalite kriterlerinin yorumlanmasinda ve sınıflarının oluşturulmasında YSKY esas alınmıştır. Çalışmada elde edilen verilerin istatistiksel analizi, Microsoft Excel programı kullanılarak hesaplanmıştır. Su numunelerin her biri için analizler üç farklı zamanda ve kendi içinde üç tekrarlı olacak şekilde gerçekleştirilmiş, elde edilen verilerin ortalama değerleri hesaplanarak tabloda belirtilmiştir (Tablo 3).

\subsection{IHA Verilerinin Elde Edilmesi ve Analiz Metodolojisi}

Çalışmada, İHA uygulamaları, uçuş öncesi, uçuş ve uçuş sonrası olmak üzere üç ana aşamada gerçekleştirilmiş ve izlenen metodoloji Şekil 3'de sunulmuştur. Üç numune alım bölgesinde ikişer periyot olmak üzere toplamda altı uçuş yapılmıştır. Metodolojiye uygun olarak yüksek çözünürlüklü İHA hava fotoğrafları elde edilmiş ve Agisoft Metashape yazılımında geometrik yöneltme (doğrulama) işlemleri gerçekleştirilerek hava fotoğraflarından yüksek doğruluklu ortomozaikler üretilmiştir (Sefercik vd. 2020).

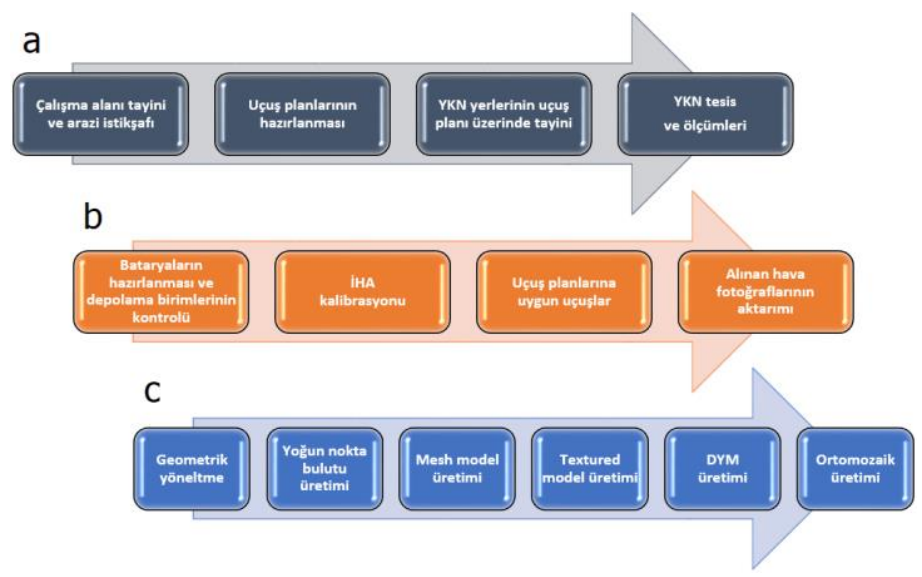

Şekil 3. IHA veri alımı ve ortomozaik üretim metodolojisi: (a) uçuş öncesi, (b) uçuş, (c) uçuş sonrası işlem adımları

Aydınlar Çayı üzerindeki üç çalışma alanında, Haziran ve Aralık 2019 tarihlerinde alınmış üç bantlı (kırmızı, yeşil, mavi) İHA hava fotoğraflarından üretilen altı adet ortomozaik üzerinde Çayın fiziko-kimyasal parametrelerinin gösterdiği değişkenliklerin spektral analizleri yapılmıştır. Spektral analizlerde, uçuşlar Haziran ve Aralık aylarında yapıldığından dolayı oluşan iklimsel değişikler ve özellikle güneş açısına bağlı olarak (görüntülerde meydana gelen spektral etkilerin eleminasyonu yapabilmek için) görüntü bantlarının histogram eşitlemesi yapılmıştır. Histogram eşitleme işleminde her üç çalışma alanı için de Aralık tarihli ortomozaikler Haziran tarihli ortomozaiklere eşitlenmiştir. Histogram eşitlenen ortomozaikler üzerinde ilk olarak spektral yorumlamalar için oldukça etkili bir metot olan bant oranı (band ratio) analizleri gerçekleştirilmiş ve kırmızı ile yeşil görüntüleme bantları kullanılmıştır (Kavzoglu ve ark., 2015). Bant oranı analizlerinin ardından su numunelerinin alındığı noktalarda oluşturulan roi (region of interest)'ler üzerinde Haziran ve Aralık tarihli ortomozaiklerin spektral bant kombinasyonu (minimum, maksimum ve ortalama dalgaboyu vb.) gibi çok parametreli uyum analizleri gerçekleştirilmiştir.

\section{Araştırma Sonuçları ve Tartışma}

Aydınlar Çay’ından üç farklı dönemde alınan su numunelerine ait fiziko-kimyasal su kalite parametreleri ile ilgili ölçüm sonuçları ve bu ölçüm sonuçlarının oluşturmuş olduğu su kalite sınıfları sırasıyla Tablo 3 ve Tablo 4'de gösterilmiştir. Elektriksel iletkenlik 2019 Haziran ayında, en yüksek 1. örneklem noktasında ölçülmüş ve $1457 \mu \mathrm{S} / \mathrm{cm}$ olarak bulunmuştur. Ölçülen en düşük değer ise $503 \mu \mathrm{S} / \mathrm{cm}$ ile 2019 Aralık ayı 3. örneklem noktasıdır. Ülkemizde rapor edilen çalışmalarda en düşük iletkenlik değeri $(166 \mu \mathrm{S} / \mathrm{cm})$ Sivas Kuruçay'da yağışlı dönem içerisinde tespit edilmiştir (Mutlu ve Uncumusaoğlu, 2016). Diğer çalışmalar sırasıyla, Aksu Nehri'nde kurak dönemde 739 $\mu \mathrm{S} / \mathrm{cm}$ ve yağışlı dönemde $690 \mu \mathrm{S} / \mathrm{cm}$, Mert Çayı'nda ortalama $1087 \mu \mathrm{S} / \mathrm{cm}$, Bulakbaşı Çayı'nda ortalama $779.6 \mu \mathrm{S} / \mathrm{cm}$, Kozlu deresinde ise kurak dönemde iki ayrı noktada $1206 \mu \mathrm{S} / \mathrm{cm}$ ve $2823 \mu \mathrm{S} / \mathrm{cm}$ ve Bartın Nehri'nde ortalama $465 \mu \mathrm{S} / \mathrm{cm}$ olarak bulunmuştur (Şener ve ark., 2017; Maraşlıoğlu ve ark., 2017; Şen ve Aksoy, 2015; Zeydan ve ark., 2019; Güneş, 2019). Literatürdeki çalışmalar ile karşılaştırıldığında, Aydınlar Çayının kurak dönemde ölçülen iletkenlik değerlerinin $1062 \mu \mathrm{S} / \mathrm{cm}$ (2.nokta) ve $1457 \mu \mathrm{S} / \mathrm{cm}$ (1.nokta) ile yüksek olduğu söylenebilir. $\mathrm{Bu}$ çalışmadaki 1. örneklem noktası, Karadeniz'e yakın olduğu için ölçülen iletkenlik değerinin diğer noktalara göre daha yüksek olması beklenen bir olaydır. Ancak önceki numune alma noktalarında ölçülen yüksek iletkenlik değerlerinin ise yüksek olması, Aydınlar Çayının deşarjlar ile kirletildiğini ve suyun kalitesinin azalmış olduğunu göstermektedir. YSKY'ne göre kalite sınıflandırmasında II. kalite su sinıfinda yer almaktadır (Tablo 4).

Bulanıklık, askıdaki kolloidal ya da çözünmüş halde bulunan maddelerden dolayı dağılan ışığın ölçümüdür. Aydınlar Çayında 3 farklı dönemde ve 3 farklı noktada ölçülen bulanıklık değerleri ortalama 5 NTU üzerinde çıkmıştır. Bulanıklık ile ilgili YSKY'e göre belirlenmiş bir sınıflandırma bulunmasa da Dünya Sağlık Örgütü (2008) ve EPA ya göre (2009) değerler yüksek bulunmuştur. Bunun yanında, 2019 Haziran ayında (kurak dönem) AKM değeri ortalama $63.2 \mathrm{mg} / \mathrm{L}$ olarak ölçülürken, diğer zamanlarda sirasiyla ortalama $46.8 \mathrm{mg} / \mathrm{L}$ (Eylül 2019) ve 26.9 mg/L (Aralık 2019-yağışlı dönem) olarak tespit edilmiştir. Tablo 3'e bakıldığında, Aralık ayındaki ölçümlerde elde edilen AKM değerlerinin düşük (diğer zamanlara göre) çıkmasının nedeninin yağışlar olduğu düşünülmektedir. Diğer taraftan, 2. ve 1. noktada AKM değerlerinin (kurak dönemde) yüksek çıkması ise, suyun 
oldukça kirli ve bulanık olduğunu ve bunun nedeninin de, noktalar etrafinda bulunan yerleşim yerlerinden çıkan evsel ya da endüstriyel kuruluşların oluşturmuş olduğu atık su deşarjlarından kaynaklandığı düşünülmektedir. Literatürde, Çoruh Nehri'ndeki AKM değerlerinin 2 farklı noktada $16 \mathrm{mg} / \mathrm{L}$ ve $17 \mathrm{mg} / \mathrm{L}$ olduğu rapor edilmiştir (Birici ve ark., 2017). Kozlu deresinde yapılan çalışmada ise, en yüksek Haziran (kurak) döneminde 3. noktada $112 \mathrm{mg} / \mathrm{L}$ değer ölçülürken, Aralık döneminde ise $1 \mathrm{mg} / \mathrm{L}$ altına düştüğü tespit edilmiştir (Zeydan ve ark., 2019). Suyun sıcaklığı, kimyasal reaksiyonların hızını, oksijen miktarını ve su içerisindeki canlılığ 1 doğrudan etkilemektedir. Farklı zamanlarda ölçülen sıcaklık değerlerinin ortalamalarına bakıldığında, en yüksek sıcaklık ölçümünün kurak dönem (Haziran) içerisinde gerçekleştiği $25.4{ }^{\circ} \mathrm{C}$, en düşük değerin ise yağışlı dönemde (Aralık) $9.4{ }^{\circ} \mathrm{C}$ olduğu görülmektedir (Tablo 3). Bu veriler 1şığında, YSKY'ne göre ortalama sıcaklık değerleri I. sınıf su kalitesi sınıfına girmektedir. Çözünmüş Oksijen (ÇO), canlı yaşamı için kritik öneme sahip olan çözünmüş oksijenin varlığı/yokluğu, yüzeysel sularda kirliliğin en önemli göstergesidir. Bu çalışmada, Haziran 2019 döneminde ortalama ÇO konsantrasyonu $2.24 \mathrm{mg} / \mathrm{L}$ olarak belirlenmiş olup IV. kalite su sınıfı aralığında yer almaktadır. Aynı şekilde, Eylül 2019 ve Aralık 2019 dönemlerine ait ÇO konsantrasyon değerleri ortalama $2.54 \mathrm{mg} / \mathrm{L}$ ve $3.40 \mathrm{mg} / \mathrm{L}$ olarak ölçülmüş ve sırasıyla IV ve III. sınıf su kalitesi sınıfında yer almıştır (YSKY). Yüzeysel sularda, suyun canlılar için en uygun ÇO konsantrasyonunun 4.0$6.0 \mathrm{mg} / \mathrm{L}$ aralığında olduğu rapor edilmiştir (Avvannavar ve Shrihar, 2008). Bu nedenle, Aydınlar çayındaki ÇO konsantrasyonun ortalama değerlerine bakıldığında tüm noktalarda sucul canlılar için biyolojik yaşamın yeterli uygunlukta olmadığı belirlenmiştir (Tablo 3). Literatürde, Bartın Nehri'nde ÇO konsantrasyonu ortalama $10 \mathrm{mg} / \mathrm{L}$ (I.sınıf), Kızılırmak nehrinde ise ortalama $10,3 \mathrm{mg} / \mathrm{L}$ (I.sınıf) olarak belirlenmiştir (Güneş, 2019; Aras ve İpek, 2019).

pH: Yapılan çalışmada, kurak dönem (Haziran 2019) içerisinde ki ortalama $\mathrm{pH}$ değeri 8.32 iken, diğer dönemlerde ortalama pH değerleri (Eylül 2019 ve Aralık 2019 (yağışl1)) 7.77 ve 7.67 ölçülmüştür. Dolayısıyla, suyun pH'ının yağışlı dönemde kurak döneme oranla biraz daha temiz olduğu söylenebilir. $\mathrm{pH}$ değerlerine bakıldığında, Aydınlar çayı alkali özellik gösterirken, YSKY'ne göre I. sınıf su kalitesine sahiptir (Tablo 4). Literatürde, Karadeniz bölgesinde yapılan çalışmalarda suların bir miktar bazik olduğu rapor edilmiş (Maraşlığlu vd. 2017) ve çalışmamıza benzer şekilde evsel ve endüstriyel atıksu deşarjlarının etkisi altında olan nehir veya dereler için de bazik pH değerleri bildirilmiştir (Ucun, 2016; Zeydan, 2019). Biyolojik Oksijen İhtiyacı (BOİ), aerobik ortamda mikroorganizmalar tarafından parçalanabilen organik maddelerin ayrıştırılması için gerekli olan oksijen miktarıdır. BOİ değerinin küçük olması suyun temiz olduğunu veya mikroorganizmaların sudaki organik maddeyi tüketmediğini göstermektedir. Tablo 3'de numune alma noktalarındaki BOİ değerlerinin $6.9-23.5 \mathrm{mg} / \mathrm{L}$ arasında değiştiğ gözlenmiştir. En yüksek değer 1. noktada ve 2019 Haziran (kurak) ayında görülürken en düşük değer ise 3. noktada 2019 Aralık (yağışlı dönem) ayında ölçülmüştür. Tablo 3'de tüm nokta ve dönemlerde, YSKY'ne göre BOİ değerlerinin 2019 haziran ayı ortalamas1 $20.14 \mathrm{mg} / \mathrm{L}$ ile IV. Sınıf, $12.64 \mathrm{mg} / \mathrm{L}$ (2019 Eylül) ile III.sinıf ve 8.14 mg/L (2019 Aralık) ile de III. sinıf su kalitesine sahip olduğu belirlenmiştir. Literatürde, Hacioğlu ve arkadaşlarının yapmış olduğu su kalitesi çalışmasında BOİ değerleri yüksek (IV.sınıf), Topal ve arkadaşlarının yapmış olduğu çalışmada ise düşük (I.sınıf) olarak rapor edilmiştir (Hacioglu ve Dülger, 2009; Topal ve Topal, 2015). Kimyasal e-ISSN: 2148-2683
Oksijen İhtiyacı (KOİ), evsel ve endüstriyel atıksuların kirlilik derecesini belirlemede kullanılan önemli bir su kalite parametresidir. $\mathrm{Bu}$ yöntemde, organik maddelerin kimyasal reaksiyonlarla parçalanması sırasında ihtiyaç duyulan oksijen miktarı ölçülmektedir. KOİ değeri ne kadar yüksek olursa, su içerinde de bulunan organik madde miktarı o kadar fazla olur. Çalışmamızda, KOİ değerleri 61.5-271.2 mg/L aralığında değişmektedir (Tablo 3). Aralık döneminde yağışlara bağlı olarak KOİ değerinin düştüğü görülmektedir. YSKY'ne göre tüm zamanlarda, KOİ konsantrasyonlarının ortalama değerlerine bakıldığında su kalitesinin IV. sınıf olduğu belirlenmiştir (Tablo 4). Bu değerlerin yüksek olması Çay'a evsel ve endüstriyel olarak atıksu deşarjlarının yapıldığını göstermektedir. Literatürde, çalışmamızla benzer sonuçlar sergileyen araştırmalar rapor edilmiştir (Mutlu ve Uncumusaoğlu, 2016; Şener ve ark., 2017).

Toplam fosfor (TP): Fosfor, ötrofikasyona sebep olan sınırlayıcı besin maddelerinden biridir. Gıda endüstrisi atıkları, deterjan atıkları ve suni gübreler sudaki fosfor kaynaklarıdır (Maraşlıŏlu vd. 2017). Yapılan çalışmada, toplam fosfor konsantrasyonu $0.035 \mathrm{mg} / \mathrm{L}$ ile $0.522 \mathrm{mg} / \mathrm{L}$ aralığında değişmiş olup, noktasal bazda ortalama değerler Haziran 2019 için 0.296 mg/L, Eylül 2019 için 0.200 mg/L ve Aralık 2019 için 0.182 mg/L olarak ölçülmüştür. Literatürde, kurak dönemde ölçülen fosfor değerlerinin düşük olduğu rapor edilmiştir (Søndegaard ve ark., 2001). Çalışmamızda, yağışlı dönemde yağmurunda etkisiyle çayda meydana gelen seyrelme fosfor konsantrasyonun düşmesine neden olmuştur. Tablo 3'e bakıldığında, özellikle 3. noktanın etrafında bulunan yerleşik köyler (evsel deşarj) ve tarımsal araziler fosfor konsantrasyonun fazlalığını açıklamaktadır. Sonuçlar yönetmelikle karşılaştırıldığında su kalitesinin noktasal ve zamansal bazda farklılık gösterdiği görülmüş ve III. sınıf (kurak dönem) ile II. Sınıf (yağışlı dönem) olduğu belirlenmiştir. Elde edilen sonuçlar literatür ile benzer özellikler göstermektedir (Zeydan ve ark., 2019; Günes, 2019). Toplam Kjeldahl Azotu: Sucul ekosistemlerde bulunan azot, azot nitrit (NO2), nitrat (NO3) ve amonyum (NH4) azotu şeklinde karşımıza çıkar. Bu bileşiklerin yüksek konsantrasyonları suda yaşayan tüm canlılar için toksik etkiler gösterir. Ayrıca, ötrofikasyonda sınırlayıcı elementlerden biridir. Toplam Kjeldahl Azotu (TKA), organik azot ve amonyak azotunun birleşimidir. Tablo 3'de, TKA değerleri $7.0 \mathrm{mg} / \mathrm{L}$ ile $25.4 \mathrm{mg} / \mathrm{L}$ arasında değişiklik göstermektedir. TKA değerlerinin ortalamalarına bakıldığında 2019 Haziran 20.14 mg/L, 2019 Eylül 14.40 mg/L ve 2019 Aralık $13.91 \mathrm{mg} / \mathrm{L}$ dir. YSKY'ne göre tüm nokta ve zamanlarda ölçülen örneklerin su kalite değerleri IV. sınıf olarak bulunmuştur (Tablo 4). TKA değerinin yüksek olmasının nedeni Çay'ın etrafında bulunan yerleşim yerlerinin ve endüstriyel kuruluşların atık sularını belirlenen noktalar yakınından çaya deşarj etmesi olarak açıklanabilir. Yağ-Gres: En yüksek yağ-gres değeri $0.042 \mathrm{mg} / \mathrm{L}$ ile 2. örneklem noktasında 2019 Eylül ayı içerisinde iken, en düşük değer ise $0.0021 \mathrm{mg} / \mathrm{L}$ ile 3 . örneklem noktasında 2019 Aralık ayı içerisinde tespit edilmiştir (Tablo 3). Bulunan değerlerin ortalamasına bakıldığında tüm örneklem noktaları ve zaman dilimlerinde YSKY'ne göre su kalitesi I. sınıf olarak belirlenmiştir (Tablo 3 ve 4). Çay'ın üst kısımlarında (3.örneklem noktası) akıntının hızlı ve yağışların (Aralık) fazla olması Çayda seyrelmeye neden olduğu için bunun değerlere yansıdığı düşünülmektedir. Literatürde çalışmamıza benzer sonuçlar rapor edilmiştir (Zeydan ve ark., 2019). Aydınlar Çayı'nda gerçekleştirilen İHA uçuşları ile üç çalışma alanında hava fotoğraflarından elde edilen ortomozaikler Şekil 4'te verilmiştir. Metodoloji bölümünde de belirtildiği üzere, ortomozaikler üzerinde mevsime bağlı iklim değişikliklerinin 
Tablo 3: Haziran 2019, Eylül 2019 ve Aralık 2019 dönemlerine ait su kalitesi analiz sonuçları

\begin{tabular}{|c|c|c|c|c|c|c|c|c|c|c|c|}
\hline & pH & \begin{tabular}{|c} 
iletkenlik \\
$(\mu \mathrm{S} / \mathrm{cm})$
\end{tabular} & $\begin{array}{c}\text { Bulanıklık } \\
\text { (NTU) }\end{array}$ & \begin{tabular}{|c|}
$\mathbf{A K M}$ \\
$(\mathbf{m g} / \mathbf{L})$
\end{tabular} & $\begin{array}{c}\text { Sicaklık } \\
\left({ }^{\circ} \mathbf{C}\right)\end{array}$ & $\begin{array}{c}\mathrm{ÇO} \\
(\mathrm{mg} / \mathrm{L})\end{array}$ & \begin{tabular}{|c|} 
BOİ5 \\
$(\mathrm{mg} / \mathrm{L})$
\end{tabular} & $\begin{array}{c}\text { KOİ } \\
(\mathbf{m g} / \mathbf{L})\end{array}$ & $\begin{array}{c}\text { TF } \\
(\mathrm{mg} / \mathrm{L})\end{array}$ & $\begin{array}{c}\text { TKA } \\
(\mathbf{m g} / \mathbf{L})\end{array}$ & $\begin{array}{c}\text { Yağ-gres } \\
(\mathbf{m g} / \mathbf{L})\end{array}$ \\
\hline & \multicolumn{11}{|c|}{ I. nokta (Erdemir) } \\
\hline Haziran 2019 & 8.25 & 1457 & 8.66 & 111 & 25 & 3.5 & 23.5 & 201.5 & 0.153 & 25.40 & 0.008 \\
\hline Eylül 2019 & 7.46 & 1201 & 9.07 & 77 & 14 & 3.3 & 15.7 & 271.2 & 0.039 & 21.51 & 0.009 \\
\hline \multirow[t]{2}{*}{ Aralık 2019} & 7.71 & 1021 & 8.83 & 38.5 & 9 & 4.8 & 10.2 & 132.0 & 0.035 & 20.05 & 0.005 \\
\hline & \multicolumn{11}{|c|}{ II.nokta (TatMetal) } \\
\hline Haziran 2019 & 8.37 & 1062 & 38.66 & 77 & 25 & 1.7 & 17.7 & 129.6 & 0.214 & 21.01 & 0.037 \\
\hline Eylül 2019 & 8.01 & 1133 & 31.09 & 56 & 14 & 2.3 & 10.1 & 125.9 & 0.128 & 14.71 & 0.042 \\
\hline \multirow[t]{2}{*}{ Aralık 2019} & 7.66 & 921 & 29.84 & 32 & 8 & 2.8 & 7.3 & 95.8 & 0.090 & 13.70 & 0.019 \\
\hline & \multicolumn{11}{|c|}{ III. Nokta (Hamzafakılı) } \\
\hline Haziran 2019 & 8.54 & 799 & 15.32 & 60 & 26 & 1.5 & 19.2 & 66.9 & 0.522 & 14.00 & 0.0025 \\
\hline Eylül 2019 & 7.84 & 617 & 14.56 & 42 & 17 & 2.0 & 12.1 & 74.5 & 0.433 & 7.00 & 0.003 \\
\hline \multirow[t]{2}{*}{ Aralık 2019} & 7.62 & 503 & 12.11 & 28 & 11 & 2.6 & 6.9 & 61.5 & 0.421 & 8.00 & 0.0021 \\
\hline & \multicolumn{11}{|c|}{ Ortalama değerler } \\
\hline Haziran 2019 & 8.32 & 1106 & 20.95 & 82.67 & 25.34 & 2.24 & 20.14 & 132.7 & 0.296 & 20.14 & 0.016 \\
\hline Eylül 2019 & 7.77 & 983.7 & 14.91 & 58.34 & 15.00 & 2.54 & 12.64 & 157.2 & 0.200 & 14.40 & 0.018 \\
\hline Aralık 2019 & 7.67 & 815 & 16.93 & 32.84 & 9.34 & 3.40 & 8.14 & 96.44 & 0.182 & 13.91 & 0.0087 \\
\hline
\end{tabular}

Tablo 4: Yerüstü Su Kalitesi Yönetmeliği ekinde (EK-5) yer alan "Kıta içi Yüzeysel Su Kaynaklarının Genel Kimyasal ve Fizikokimyasal Parametreler Açısından Sinıflarına Göre Kalite Kriterleri"

\begin{tabular}{|c|c|c|c|c|c|c|c|c|c|c|c|}
\hline & pH & $\begin{array}{c}\text { İletkenlik } \\
(\mu \mathrm{S} / \mathrm{cm})\end{array}$ & $\begin{array}{c}\text { Bulanıklık } \\
\text { (NTU) }\end{array}$ & $\begin{array}{c}\mathbf{A K M} \\
(\mathrm{mg} / \mathrm{L})\end{array}$ & $\begin{array}{c}\text { Sicaklık } \\
\left({ }^{\circ} \mathbf{C}\right)\end{array}$ & $\begin{array}{c}\mathbf{C ̧ O} \\
(\mathrm{mg} / \mathrm{L})\end{array}$ & $\begin{array}{c}\text { BOİ5 } \\
(\mathrm{mg} / \mathrm{L})\end{array}$ & \begin{tabular}{|c|}
$\mathbf{K O I I}$ \\
$(\mathbf{m g} / \mathbf{L})$
\end{tabular} & $\begin{array}{c}\mathbf{T F} \\
(\mathrm{mg} / \mathrm{L})\end{array}$ & $\begin{array}{c}\text { TKA } \\
(\mathrm{mg} / \mathrm{L})\end{array}$ & $\begin{array}{c}\text { Yağ-gres } \\
(\mathrm{mg} / \mathrm{L})\end{array}$ \\
\hline & \multicolumn{11}{|c|}{ I. nokta (Erdemir) } \\
\hline Haziran 2019 & I & II & - & - & I & IV & III & III & III & IV & I \\
\hline Eylül 2019 & $\mathrm{I}$ & II & - & - & $\mathrm{I}$ & IV & III & IV & III & IV & $\mathrm{I}$ \\
\hline \multirow[t]{2}{*}{ Aralık 2019} & $\mathrm{I}$ & II & - & - & I & IV & II & III & III & IV & $\mathrm{I}$ \\
\hline & \multicolumn{11}{|c|}{ II.nokta (TatMetal) } \\
\hline Haziran 2019 & I & III & - & - & I & IV & III & IV & III & IV & I \\
\hline Eylül 2019 & $\mathrm{I}$ & III & - & - & $\mathrm{I}$ & IV & III & IV & II & IV & $\mathrm{I}$ \\
\hline \multirow[t]{2}{*}{ Aralık 2019} & $\mathrm{I}$ & III & - & - & $\mathrm{I}$ & IV & II & IV & II & IV & $\mathrm{I}$ \\
\hline & \multicolumn{11}{|c|}{ III. Nokta (Hamzafakılı) } \\
\hline Haziran 2019 & $\mathrm{I}$ & III & - & - & $\mathrm{I}$ & III & IV & IV & II & IV & $\mathrm{I}$ \\
\hline Eylül 2019 & I & III & - & - & I & III & III & IV & II & IV & $\mathrm{I}$ \\
\hline \multirow[t]{2}{*}{ Aralık 2019} & $\mathrm{I}$ & III & - & - & $\mathrm{I}$ & III & III & IV & II & IV & $\mathrm{I}$ \\
\hline & \multicolumn{11}{|c|}{ Ortalama değerler } \\
\hline Haziran 2019 & I & III & - & - & $\mathrm{I}$ & IV & IV & IV & III & IV & I \\
\hline Eylül 2019 & $\mathrm{I}$ & II & - & - & $\mathrm{I}$ & IV & III & IV & III & IV & $\mathrm{I}$ \\
\hline Aralık 2019 & $\mathrm{I}$ & II & - & - & $\mathrm{I}$ & III & III & IV & III & IV & $\mathrm{I}$ \\
\hline
\end{tabular}


özellikle güneş açısı farklılıklarına bağlı spektral etkilerinin eleminasyonu için bant histogram eşitleme çalışması yapılmıştır. Aralık 2019 tarihindeki uçuşlardan elde edilen ortomozaiklerin Haziran 2019 tarihli ilk uçuşlardan üretilmiş ortomozaiklere band histogramı eşitlenmiş durumları Şekil 5 'te yer almaktadır.

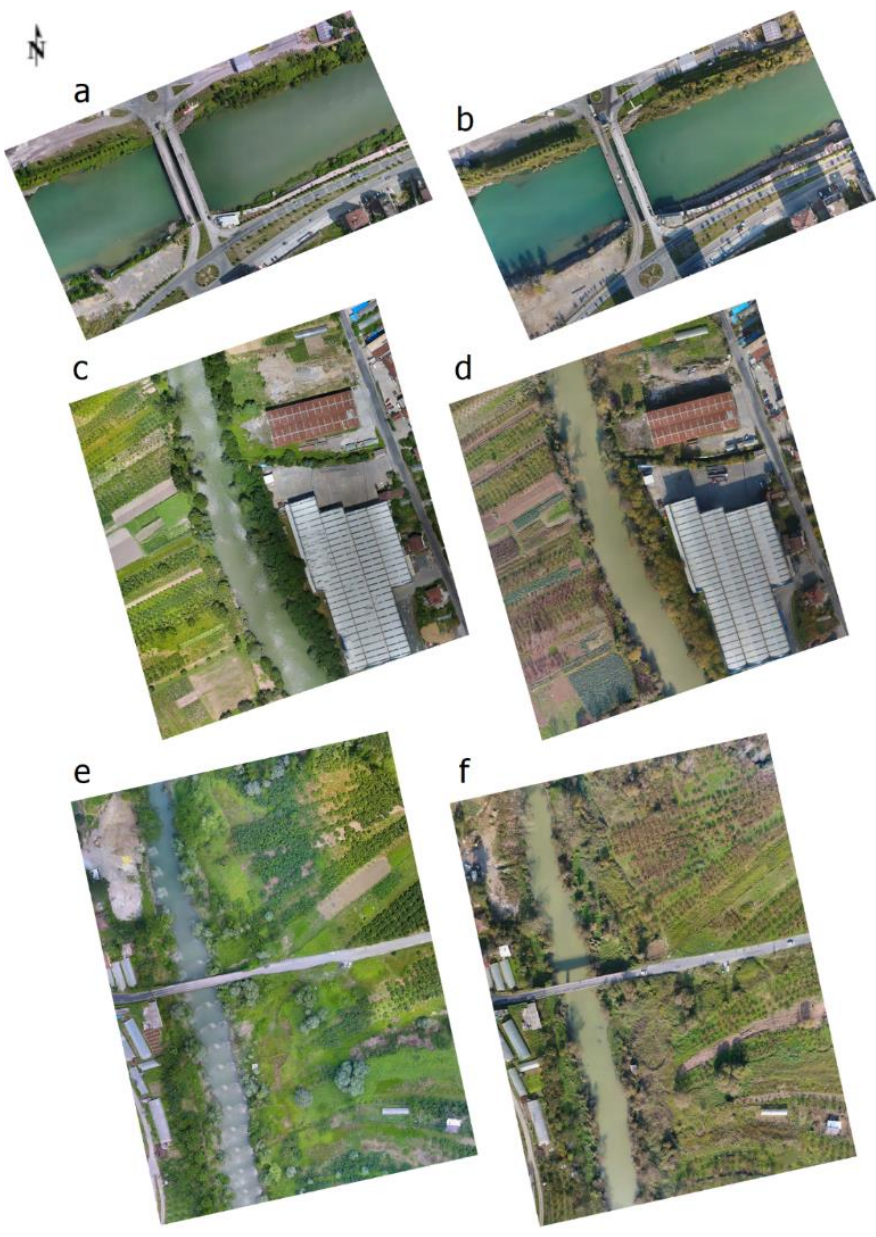

Şekil 4. İHA hava fotoğraflarından üretilen ortomozaikler: (a) Erdemir test alanı ilk uçuş, (b) Erdemir test alanı ikinci uçuş, (c) Tatmetal test alanı ilk uçuş, (d) Tatmetal test alanı ikinci uçuş, (e) Hamzafakılı test alanı ilk uçuş, (f) Hamzafakılı test alanı ikinci uçuş.

Numune alınan çalışma alanlarında, Aydınlar Çayı üzerindeki spektral etkilerinin belirlenmesi amacıyla yapılan kırmızı/yeşil bant oranı analizlerine ilişkin sonuçlar Şekil 6'te verilmiştir. Bant oranı analizleri, Erdemir test alanında yağışlı dönem (Aralık 2019) kurak döneme (Haziran 2019) göre çok daha dalgalı yapıya sahip olduğundan dolayı deniz suyu iç kısımlara doğru daha fazla nüfuz etmiş ve Çayın spektral yapısında ciddi değişikliğe neden olmuştur. Çalışma alanlarında spektral bantların dalgaboylarına bağlı bant kombinasyonu, minimum, maksimum ve ortalama dalgaboyu analiz sonuçları Şekil 6'da sunulmuştur. Şekil 6'a bakıldığında, ilk göze çarpan durumun spektral bantların dalga boyu grafiklerinde sol tarafta yer alan ilk uçuş değerlerinin sağ tarafta yer alan ikinci uçuş değerlerine göre daha düz ve yumuşak bir yapıda olmasıdır. Bu durum, Aydınlar Çayı'nın fizikokimyasal parametrelerinin kurak dönemde daha az değişken yapıda olduğunu yağışlı dönemde ise özellikle iklimsel etkilerle çok daha bulanık bir yapıda olduğunu kanıtlamaktadır. Diğer bir durum, Hamzafakılı çalışma alanında spektral bant dalga boyu grafiklerinde bant kombinasyonlarının diğer iki çalışma alanına göre farklı olmasıdır. Bu alanda, ilk uçuş grafiğginde yeşil ve mavi dalgaboyları kesişim gösterirken diğer iki alanda bu bantların e-ISSN: 2148-2683 belirgin kesişimleri bulunmamaktadır. Bu durum, Hamzafakılı çalışma alanının etrafında bulunan tarımsal arazi yapısının yoğun olması olarak yorumlanabilir. Diğer bir sonuç ise Erdemir ve Tatmetal çalışma alanlarında bir ve ikinci uçuşlarda dikkate değer ölçüde değişkenlik göstermeyen spektral bant diziliminin Hamzafakılı çalışma alanında tersine dönmesidir. Bu durumda yine tarım arazilerinin etkisi olarak açıklanabilir.

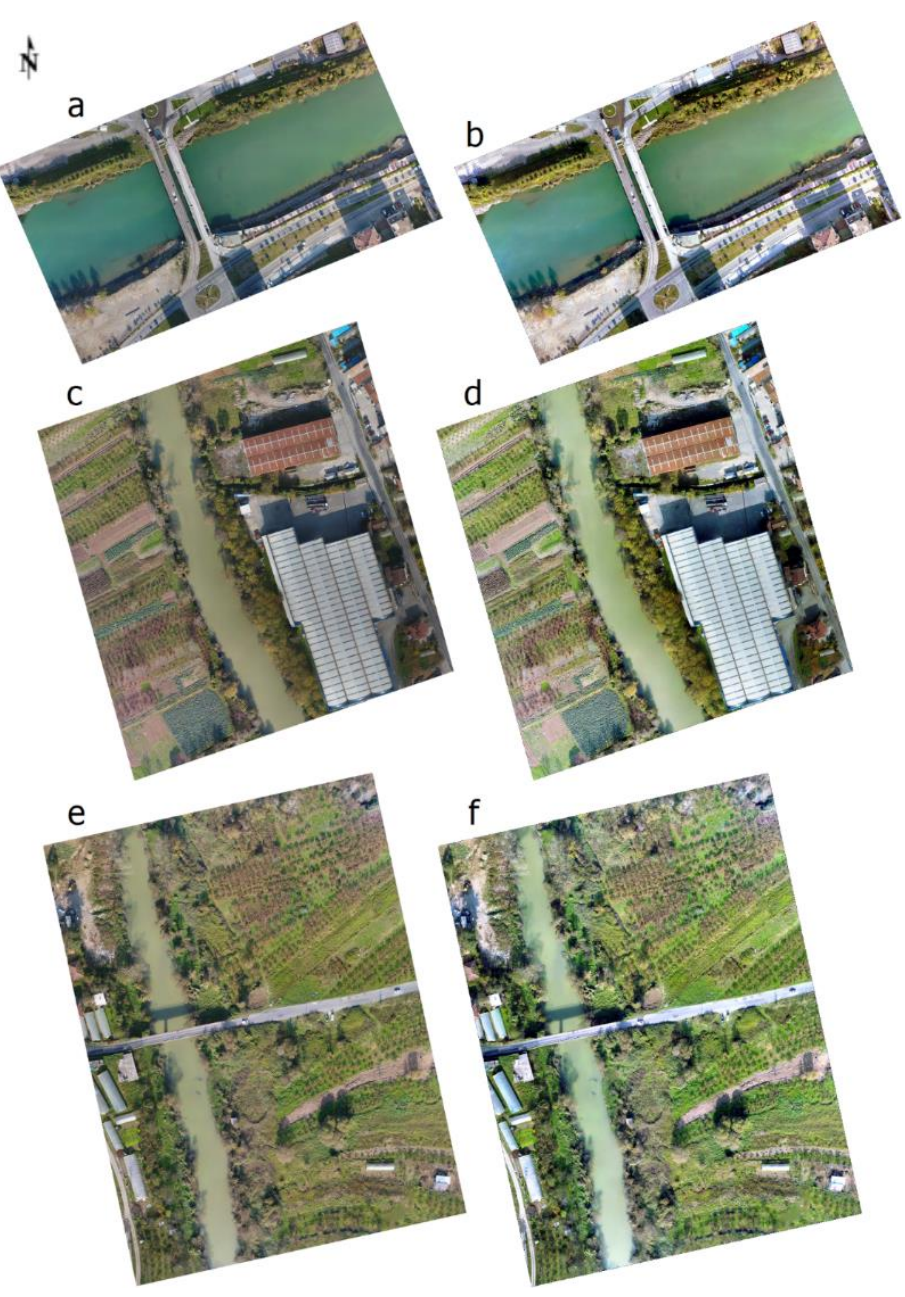

Şekil 5. Histogram eşleştirme sonucu üretilen ortomozaikler: (a) Erdemir test alanı ikinci uçuş, (b) Erdemir test alanı ikinci uçuş histogram eşitlenmiş, (c) Tatmetal test alanı ikinci uçuş, (d) Tatmetal test alanı ikinci uçuş histogram eşitlenmiş, (e) Hamzafakılı test alanı ikinci uçuş, (f) Hamzafakılı test alanı ikinci uçuş histogram eşitlenmiş.

Bu çıkarımların yanısıra, Şekil 6'da yer alan sonuçlar, laboratuar ortamında fiziko-kimyasal parametreler kullanılarak elde edilen su numune test sonuçları ile karşılaştırmalı olarak değerlendirilmiş ve beraber yorumlanmıştır. Değerlendirmede, suyun spektral yapısına en çok etki edecek faktörler olan ÇO, BOİ5, KOİ, TF ve TKA parametreleri dikkate alınmıştır. İlk ve ikinci uçuş periyotlarında fiziko-kimyasal parametrelerin gösterdikleri değişim ve bağımsız spektral bantların dalgaboyu değişimleri Tablo 5 ve 6'da sunulmuştur. Şekil 6'da tüm çalışma alanları için standart olan gösterge tüm spektral bantların dalgaboyu ortalama değerlerinin ikinci uçuşlardaki görünür artışıdır. Özellikle yeşil bant dalgaboyu üç çalışma alanında da yüksek artış göstermiştir. Tablo 5 ve 6 karşılaştırıldığında aşağıdaki bilimsel çıkarımlar yapılmıştır: 
- Yeşil bant ağırlıklı olmak üzere spektral bantların dalgaboyu artışları ÇO değerinin artışını ve suyun spektral yapısına yansımasını işaret etmektedir.

- Spektral bant dalgaboyları arttıkça BOİ5, KOİ, TF ve TKA fiziko-kimyasal parametrelerinde düşüş olduğu gözlemlenmiştir.

- Erdemir çalışma alanında, ÇO değerinde meydana gelen değişim ve yeşil bant dalgaboyu değişiminin tamamen örtüştüğü görülmektedir.

- TKA değerindeki ortalama değişimin, yeşil bant dalgaboyu ortalama değişimine ters orantılı olarak parallelik gösterdiği belirlenmiş̧tir.

- Tatmetal çalışma alanında KOİ değerindeki düşüş yüzdesinin tüm spektral bandların artış yüzdesine paralel olduğu saptanmıştır.

- KOİ değeri değişim oranının endüstriyel alanlar olan Erdemir ve Tatmetal'de yeşil bant dalgaboyu değişimiyle ters orantılı olarak paralellik gösterdiği tespit edilmiștir. Tarım yoğun Hamzafakıılı alanında ise böyle bir durum söz konusu değildir.

- BOİ5 parametresine ait değişim yüzdeleri oldukça paralel seyretmekte olup mavi bant dalgaboyu değissimlerinde de benzer durum tespit edilmiştir.

- TF parametresinin tüm çalışma alanı için değişim oranı ile kırmızı bant dalgaboyunun değişim oranlarının ters orantılı olarak paralellik gösterdiği belirlenmiştir.

Tüm bu değerlendirmeler ışığında, su kalitesini etkinleyen başlıca fiziko-kimyasal ÇO, BOİ5, KOİ, TF ve TKA parametrelerinin İHA hava fotoğraflarından elde edilen ortomozaiklerin spektral bandlarıyla olan ilişkileri açık şekilde ortaya konmuştur. Özellikle yeşil bantın fiziko-kimyasal parametrelerin bir çoğunun tespitinde doğrudan rol oynayabileceği sonucuna ulaşıllmıştır.

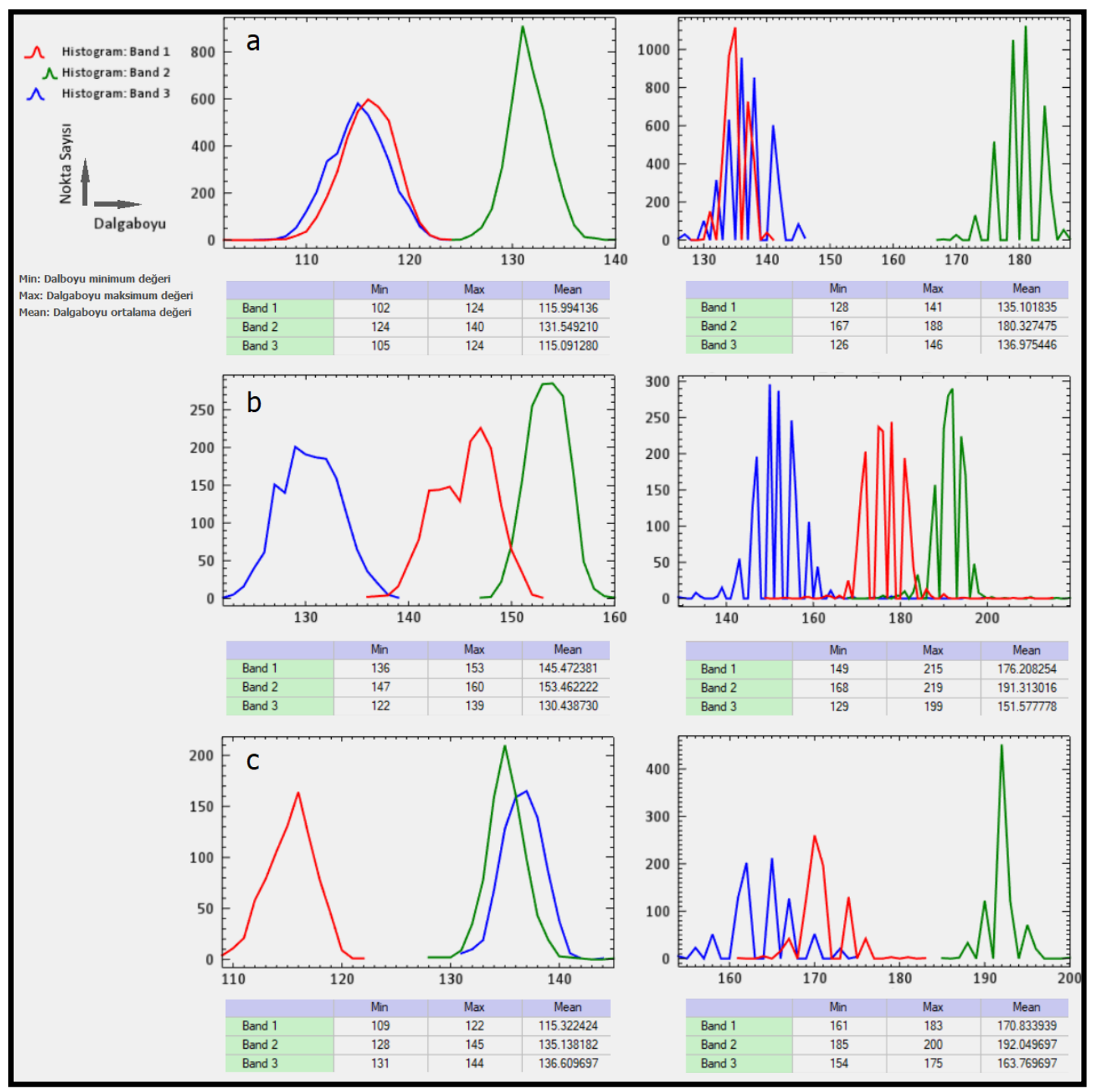

Şekil 6. Spektral bantların dalgaboylarına bağlı bant kombinasyonu, minimum, maksimum ve ortalama dalgaboyu analiz sonuçları:

(a) Erdemir test alanı (sol ilk uçuş, sağ ikinci uçuş), (b) Tatmetal test alanı (sol ilk uçuş, sağ ikinci uçuş), (c) Hamzafakılı test alanı ilk uçuş (sol ilk uçuş, sağ ikinci uçuş) 
Tablo 5. İlk ve ikinci uçuş periyotlarında fiziko-kimyasal parametrelerin gösterdikleri değiş̧im

\begin{tabular}{|c|c|c|c|c|c|c|c|c|c|c|}
\hline Uçuş Periyotu & $\begin{array}{c}\text { ÇO } \\
(\mathrm{mg} / \mathrm{L})\end{array}$ & $\begin{array}{c}\text { Değgişim } \\
(\mathbf{\%})\end{array}$ & $\begin{array}{c}\text { BOI55 } \\
(\mathrm{mg} / \mathrm{L})\end{array}$ & $\begin{array}{c}\text { Değiş̧im } \\
(\mathbf{\%})\end{array}$ & $\underset{(\mathbf{m g} / \mathbf{L})}{\text { KOİ }}$ & $\begin{array}{c}\text { Değiş̧im } \\
(\mathbf{\%})\end{array}$ & $\underset{(\mathrm{mg} / \mathrm{L})}{\mathrm{TF}}$ & $\begin{array}{c}\text { Değişim } \\
\text { (\%) }\end{array}$ & $\begin{array}{c}\text { TKA } \\
(\mathrm{mg} / \mathrm{L})\end{array}$ & $\begin{array}{c}\text { Değişim } \\
\text { (\%) }\end{array}$ \\
\hline \multicolumn{11}{|c|}{ ERDEMIR ROI } \\
\hline Haziran 2019 & 3.5 & \multirow{2}{*}{+37.1} & 23.5 & \multirow{2}{*}{-56.5} & 201.5 & \multirow{2}{*}{-35.0} & 0.153 & \multirow{2}{*}{-77.1} & 25.40 & \multirow{2}{*}{-21.1} \\
\hline Aralık 2019 & 4.8 & & 10.2 & & 132.0 & & 0.035 & & 20.05 & \\
\hline \multicolumn{11}{|c|}{ TATMETAL ROI } \\
\hline Haziran 2019 & 1.7 & \multirow{2}{*}{+64.7} & 17.7 & \multirow{2}{*}{-58.8} & 129.6 & \multirow{2}{*}{-26.1} & 0.214 & \multirow{2}{*}{-57.9} & 21.01 & \multirow{2}{*}{-34.8} \\
\hline Aralık 2019 & 2.8 & & 7.3 & & 95.8 & & 0.090 & & 13.70 & \\
\hline \multicolumn{11}{|c|}{ HAMZAFAKILI ROI } \\
\hline Haziran 2019 & 1.5 & \multirow{2}{*}{+73.3} & 19.2 & \multirow{2}{*}{-64.1} & 66.9 & \multirow{2}{*}{-8.1} & 0.522 & \multirow{2}{*}{-19.3} & 14.0 & \multirow{2}{*}{-42.9} \\
\hline Aralık 2019 & 2.6 & & 6.9 & & 61.5 & & 0.421 & & 8.0 & \\
\hline & Ort. & +58.4 & & -59.8 & & -23.1 & & -51.4 & & -32.9 \\
\hline
\end{tabular}

Tablo 6. İlk ve ikinci uçuş periyotlarında bağımsız spektral bantların dalgaboyu değişimleri

\begin{tabular}{|c|c|c|c|c|c|c|}
\hline Spektral Bant & Kırmızı & Değişim (\%) & Yeşil & Değişim (\%) & Mavi & Değişim (\%) \\
\hline \multicolumn{7}{|c|}{ ERDEMIR ROI } \\
\hline Haziran 2019 & 115.99 & \multirow{2}{*}{+16.5} & 131.54 & \multirow{2}{*}{+37.1} & 115.09 & \multirow{2}{*}{+19.0} \\
\hline Aralık 2019 & 135.10 & & 180.32 & & 136.97 & \\
\hline \multicolumn{7}{|c|}{ TATMETAL ROI } \\
\hline Haziran 2019 & 145.47 & \multirow{2}{*}{+21.1} & 153.46 & \multirow{2}{*}{+24.7} & 130.43 & \multirow{2}{*}{+16.2} \\
\hline Aralık 2019 & 176.20 & & 191.31 & & 151.57 & \\
\hline \multicolumn{7}{|c|}{ HAMZAFAKILI ROI } \\
\hline Haziran 2019 & 115.32 & \multirow{2}{*}{+48.1} & 135.13 & \multirow{2}{*}{+42.11} & 136.60 & \multirow{2}{*}{+19.9} \\
\hline \multirow[t]{2}{*}{ Aralık 2019} & 170.83 & & 192.04 & & 163.76 & \\
\hline & Ort. & +28.6 & & +34.6 & & +18.4 \\
\hline
\end{tabular}

\section{Sonuç}

Bu çalışmada, Aydınlar Çayı'ndaki su kalite parametreleri ilk kez çay boyunca çalışılmış, üç ayrı noktadan üç farklı dönemde (kurak ve yağışlı) alınan su numunelerinin fiziko-kimyasal parametreleri analiz edilmiş ve YSKY'ne göre su kalite standartlarıyla karşılaştııılarak su kalitesi sınıfları belirlenmiştir. Ayrıca, modern haritacılık teknolojilerinden olan IHHA ile tüm çalışma alanlarının hava fotoğrafları alınmış, geometrik doğrulamaları yapılmış ve üretilen ortomozaikler yardımıyla spektral band analizleri gerçekleştirilerek fiziko-kimyasal parametreler ile ilişkileri kurulmuştur.

Alınan numunelerde $\mathrm{pH}$, iletkenlik, bulanıklık, AKM, sicaklık, ÇO, BOİ, KOİ, TKA, Toplam fosfor ve yağ gres analizleri yapılmıştır. Bölgede yayılı kaynak (tarımsal faaliyet alanı) bulunmakta ve aynı zamanda noktasal kaynaklarında Çaya deşarj yapan evsel ve endüstriyel kuruluşlar olduğu tahmin edilmektedir. Genel olarak elde edilen deneysel sonuçlara bakıldığında, belirlenen parametrelere göre Aydınlar çayının su kalite sınıfının III. ve IV. kalite su sınıfı olduğu görülmektedir. Bu veriler göz önüne alındığında, Çay'ın sulama ve kullanma suyu temini yapmak, rekreasyonel amaçla suyu kullanmak ve balıkçılık faaliyetlerini gerçekleştirmek mevcut haliyle uygun görülmemektedir. Bu nedenle, Aydınlar Çayı kullanılamaz hale gelmeden önce gerekli önlemlerin alınması gerekmektedir. $\mathrm{Bu}$ önlemlerin alınmaması ve kirliliğin giderek artması sonucu çevre ve insan sağlığını olumsuz yönde etkileyecek sorunlar ortaya çıkacağı öngörülmektedir. Aydınlar Çayı'nın sürdürülebilir yönetiminin sağlanabilmesi için elde edilen sonuçlar doğrultusunda su kalitesini iyileştirebilmek için aşağıdaki öneriler sunulmuştur.

1.Aydınlar Çayına deşarj edilen evsel ve endüstriyel atık suların kirlilik yüklerinin incelenmesi gerekir.

2.Aydınlar Çayının düzenli olarak izlenmesi ve kirliliğin önlenebilmesi için gerekli çalışmaların yapılması gerekir.

3.Çayın çevresinde endüstriyel, evsel ve tarım alanlarından kaynaklı kirleticilerin girdilerinin sınır şartların altına indirilmesi veya tamamen durdurulması gerekir.

4.Fosfor ve azot girdilerinin azaltılması gerekir.

5.Bölgedeki halk bu konuda bilgilendirilmeli ve bilinçlendirilmelidir. 


\section{Teşekkür}

Bu çalışma, TÜBITAK 2209-A Üniversite Öğrencileri Araştırma Projeleri Destekleme Programı tarafından desteklenmiştir.

\section{Kaynakça}

APHA. (2005). Standard Methods of Water and Wastewater, 21 st Ed., American Public Health Association, Washington, DC., ISBN:0875530478, pp: 2-61.

Aras, S., İpek, G.G. (2019). Kızılırmak Nehri (Nevşehir) Yüzey Suyu Kalitesinin Coğrafi Bilgi Sistemleri ile Değerlendirilmesi. KSÜ Mühendislik Bilimleri Dergisi, 22 (2).

Avvannavar, M.S., Shrihar, S. (2008). Evaluation of water quality index for drinking purposes for river Netravathi, Mangalore, South India. Environ Monit Assess, 143:279.

Bat, L., Özkan, E.Y. (2015). Heavy Metal Levels in Sediment of the Turkish Black Sea Coast. Oceanography and Coastal Informatics: Breakthroughs in Research and Practice, Page 86-107.

Birici, N., Karakaya, G., Şeker, T., Küçükyılmaz, M., Balcı M., Özbey, N., Güneş, M. (2017). Çoruh Nehri su kalitesinin su kirliliği kontrolü yönetmeliğine göre değerlendirilmesi. Int. J. Pure Appl. Sci., 3(1), 54-64.

Bozcaarmutlu, A., Sapmaz, C., Aygun, Z., Arınç, E. (2009). Assessment of pollution in the West Black Sea Coast of Turkey using biomarker responses in fish. Marine Environmental Research, Volume 67, Issues 4-5, Pages $167-176$.

EPA. (2009). Ground water and drinking water, Environmental Protection Agency, U.S.

Güneş, G. 2019. Bartın Nehri'nin Fizikokimyasal Özelliklerinin Yağışlı ve Kurak dönemlerdeki Değişimi. DEÜ FMD 21(63), 761-774.

Güler, Ç., Çobanoğlu, Z. (1997). Su Kalitesi Kitabı.

Hacioglu, N., Dulger, B. (2009). Monthly variation of some physico-chemical and microbiological parameters in Biga Stream (Biga, Canakkale, Turkey). African Journal of Biotechnology, 8(9), 1929-1937.

Karakış, S., Sefercik, U.G., Atalay, C. (2018). Point-based Accuracy Anaylse of Optical Unmanned Air Vehicle Data Derived by Low Cost Action Camera, International Conference Geomapplica 2018, Geomatics, Remote Sensing Earth Observation, Syros, Yunanistan, 25-29 Haziran.

Kavzoglu, T., Colkesen, I., Yomralioglu, T. (2015). Object Based Classification with Rotation Forest Ensemble Learning Algorithm Using Very High Resolution WorldView-2 Image. Remote Sensing Letters, 6(11), 834843.

Maraşlığlu, F., Gönülol, A., Bektaş, S. (2017). Assessment of water quality in Mert Stream (Samsun, Turkey) base on some physicochemical parameters, Ecology Symposium 2017 Proceedings Book of Full Papers'in içinde, Kayseri, Turkey, ss. 77-89.

Mutlu, E., Uncumusaoğlu, A.A. (2016). Physicochemical analysis of water quality of brook Kuruçay. Turkish Journal of Agriculture - Food Science and Technology, 4(11), 991-998.

Sefercik, U.G., Tanrıkulu, F., Atalay, C. (2020). SFM Tabanlı Yeni Nesil Görüntü Eşleştirme Yazılımlarının
Fotogrametrik 3B Modelleme Potansiyellerinin Karşılaştırılması. Türkiye Fotogrametri Dergisi, Cilt: 2, Say1: 2, Sayfalar: 39-45.

Sefercik, U.G., Karakış, S., Atalay, C. (2018). Topographic Description Potential of Laser UAVs by the Side of Terrestrial Laser Scanning, International Conference Geomapplica 2018, Geomatics, Remote Sensing Earth Observation, Syros, Yunanistan, 25-29 Haziran.

Søndegaard, M., Jensen, J.P., Jeppesen, E. (2001). Retention and internal loading of phosphorus in shallow, eutrophic lakes, Scient. World J., 1, 427.

Sur, M., Sur, H.İ., Apak, R., Erçağ, E. (2012). The Pollution Status of Bottom Surface Sediments along the Turkish Coast of the Black Sea. Turkish Journal of Fisheries and Aquatic Sciences, 12: 453-460.

Şen, F., Aksoy, A. (2015). Chemical and Physical Quality Criteria of Bulakbaşı Stream in Turkey and Usage of Drinking, Fisheries, and Irrigation. Journal of Chemistry, Volume 2015, Article ID 725082, 8 pages.

Şener, Ş., Şener, E., Davraz, A. (2017). Evaluation of water quality using water quality index (WQI) method and GIS in Aksu River (SW-Turkey). Science of the Total Environment, 584-585, 131-144.

Topal, M., Topal, E.I.A. (2015). 2014-2015 Kış Sezonunda Caro Deresi (Elazığ)'nin Bazı Fizikokimyasal Parametreler Açısından Su Kalitesinin Belirlenmesi. BEÜ Fen Bilimleri Dergisi, 4(1), 43-53.

Ucun Özel, H., Gemici, B. (2016). Bartın Irmağı Kirlilik Profilinin Fiziksel Parametrelerle Belirlenmesi. Mehmet Akif Ersoy Üniversitesi Fen Bilimleri Enstitüsü Dergisi, 7(1): 52-58.

URL-1. (2018). Dünya Çevre Günü Türkiye Raporu. https://www.cmo.org.tr/resimler/ekler/0d4a5b926c005a6_ ek.pdf.

URL-2. (2018). Zonguldak İli 2018 Yılı Çevre Durum Raporu, https://webdosya.csb.gov.tr/db/ced/icerikler/zongudak_20 18-cdr_son-20190926093732.pdf.

URL-3. MGM. https://www.mgm.gov.tr/veridegerlendirme/ilve-ilceler-istatistik.aspx? $\mathrm{m}=$ ZONGULDAK.

URL-4.https://mpgm.csb.gov.tr/zonguldak-ili-1-25.000olcekli-cevre-duzeni-plani-i-82283, Ziyaret Tarihi: 30.03.2021)

Walker, D., Jakovljevic, D., Savic, D., Radovanovic, M. (2015). Multi-criterion water quality analysis of the Danube River in Serbia: A visualisation approach. Water Research, 79: $158-172$.

WHO. (2008). Guidelines for drinking-water quality, World Health Organization, Geneva, Switzerland.

YSKY (Yerüstü Su Kalitesi Yönetimi Yönetmeliği) 2015. 15.04.2015 Tarih ve 29327 Sayllı Resmi Gazete.

Zeydan, Ö., Ozdogan, N., Taştepe, P.Ş., Demirtaş, D. (2019). Kozlu Deresinde (Zonguldak) Su Kalitesinin İncelenmesi. Doğal Afetler ve Çevre Dergisi, 5(2): 187-197. 